\title{
FACTORS AFFECTING FINANCIAL CONSUMERS’ PRIVATE PENSION PLAN DECISIONS: A LITERATURE REVIEW AND A CONCEPTUAL FRAMEWORK PROPOSAL
}

\author{
Aslı Elif AYDIN ${ }^{1}$ \\ Elif AKBEN SELÇUK ${ }^{2}$
}

Başvuru Tarihi: 12.05.2016

Kabul Tarihi: 14.08.2016

\begin{abstract}
The objective of this study is to propose a framework related to financial consumers' private pension plan decisions. Specifically, we review the factors affecting consumers' participation, contribution and asset allocation decisions regarding private pensions. The factors discussed include situational and dispositional factors, personality, motivation, financial literacy, and external influences. Based on this survey of literature, we develop a number of propositions, which are expected to benefit individual retirement planners and pension institutions in gaining a better understanding of retirement saving decisions.
\end{abstract}

Keywords: Private pension plan, retirement, financial consumers, financial planning, conceptual framework JEL Codes: D11, D14, J32

\section{FINANSAL TÜKETICILERIN BİREYSEL EMEKLILIK KARARLARINI}

\section{ETKILLEYEN FAKTÖRLER: BİR LİTERATÜR TARAMASI VE KAVRAMSAL ÇERÇEVE ÖNERISI}

$\ddot{O} z$

Bu çalışmanın amacı finansal tüketicilerin bireysel emeklilik planlart ile ilgili kararlarına yönelik bir çerçeve sunmaktır. Özellikle, tüketicilerin bireysel emeklilik sistemine katılım kararl, yatırllan miktar ve varlıkların dă̆llımı ile ilgili kararlarını etkileyen faktörler gözden geçirilmiştir. Bahsedilen faktörler durumsal ve ruhsal faktörleri, kişilik özelliklerini, motivasyonu, finansal okuryazarlığl ve dış etmenleri içermektedir. Bu literatür taraması temek alınarak bireysel emeklilik danışmanları ve kurumlara emeklilik birikimlerini daha iyi anlamada yarar să̆laması beklenen bazı önermeler geliştirilmiştir.

Anahtar kelimeler: Bireysel emeklilik planı, emeklilik, finansal tüketiciler, finansal planlama, kavramsal çerçeve

JEL Kodları: D11, D14, J32

\footnotetext{
${ }^{1}$ Yrd. Doç. Dr., İstanbul Bilgi Üniversitesi, İşletme Bölümü, aslielif.aydin@bilgi.edu.tr

${ }^{2}$ Yrd. Doç. Dr., Kadir Has Üniversitesi, İşletme Bölümü, elif.akben@khas.edu.tr
} 


\section{Introduction}

Retirement saving decision has gained growing emphasis in recent years due to the aging population around the globe and its impact on macroeconomic conditions. This is even more important considering the fact that in recent years, there has been a shift of responsibility to plan for retirement from governments and corporations to individuals. Therefore, understanding the factors which might have an effect on private pension plan decisions is of utmost significance for both financial consumers and pension institutions to acquire valuable information with which to influence consumer behavior in this area (Rickwood \& White, 2009).

The objective of this study is to propose a framework related to consumers' private pension plan decisions. The key decision is whether consumers are willing to participate in a plan or not. Once the participation decision has been made, the next important choice is how much to contribute. Another plan feature that is chosen by participants is the allocation of assets within the individual's account. Some individuals might prefer riskier options with volatile returns such as stocks, while others might opt for fixed income securities. The factors affecting these three essential decisions will be the focus of this study.

In prior works, several factors affecting consumer decision making in the purchase of financial services in general, and retirement saving decisions in particular, have been investigated in isolation. However, comprehensive reviews including a large set of factors that are likely to have an impact on participants' private pension plan decisions are scarce. This paper contributes to the literature by proposing a framework which fits together several elements, some of which did not receive adequate attention in prior studies. The relation of demographic factors such as age, income, education and gender to retirement saving practices has been well established in the literature. In this paper, we rather focus on the role of personality, motivation, financial literacy, situational and dispositional factors, and external influences in explaining private pension plan decisions among financial consumers.

The framework proposed in this paper is depicted on Figure 1 that follows. Among personality factors, we discuss the role of locus of control, future time perspective and financial risk tolerance in explaining private pension plan decisions. Motivational factors comprise of involvement and the characteristics of goals such as the number of goals, goal clarity, specificity and priority. Besides, we examine the role of both objective and subjective financial literacy of consumers in determining decisions related to private pension plans. The next set of factors includes regulatory focus and mental construal which have both situational 
and dispositional features. Finally, we elaborate on external factors including family and peer influences, economic conditions and institution based conditions.

Figure 1. Conceptual Framework Of The Factors That Influence Private Pension Plan Decisions

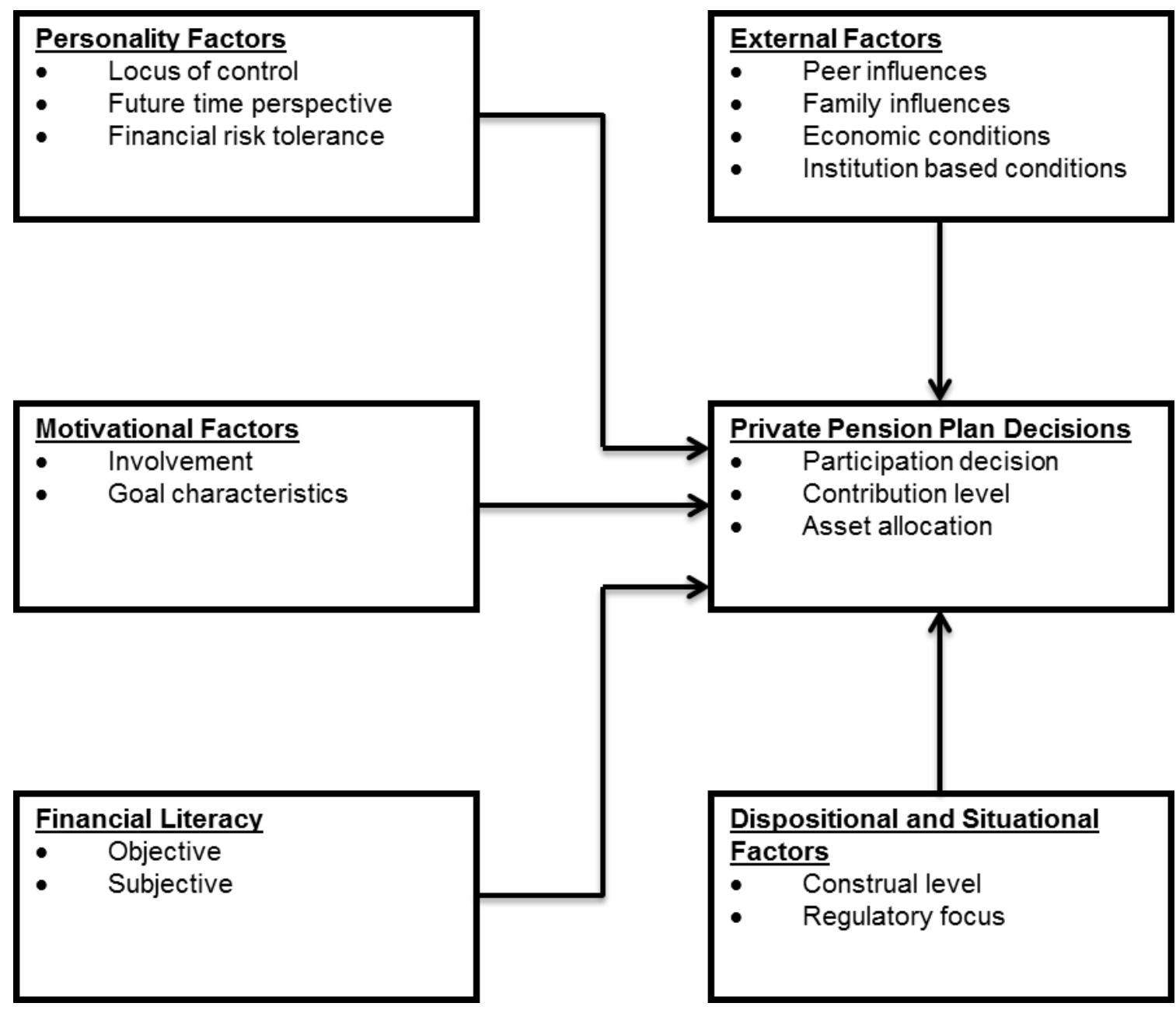

\section{Personality Factors}

\subsection{Locus of Control}

Locus of control (LOC) is a personality factor that explains differences in individuals' perception of control over the course of their lives (Rotter, 1966). Based on their locus of control, individuals can be grouped as internals, who attribute occurring events to their own actions, and consider themselves in control of their lives, and externals, who believe life events may happen independently of one's own action, and consider forces outside themselves may control their lives.

The LOC concept has been investigated within finance domain to demonstrate 
differences between internals and externals in their money attitudes, saving behavior, and financial preparedness. Overall, the studies suggest that internals believe in controlling their own fates and therefore take responsibility of their finances; whereas externals rely on other forces than themselves in determining the course of their lives; hence don't take responsibility of their finances (Lim et al., 2003; Perry and Morris, 2005). In particular, it is established that internals manage their money more carefully (Tang, 1995) and save more than others (Sakalaki et al., 2005) since they believe in controlling their own financial state and have a higher sense of responsibility for their success in life. Furthermore, it has been revealed that individuals with internal LOC orientation have an increased tendency to engage in financial preparation processes due to the fact that their likelihood to defer gratification is greater than those of individuals with external LOC orientation (Morgan \& Eckert, 2004; Plunkett \& Buehner 2007).

We summarize the above in our first two propositions:

Proposition 1a. Internals are more likely to participate in private pension plans than externals.

Proposition 1b. Internals are more likely to make larger contributions to their private pension plans than externals.

\subsection{Future Time Perspective}

Future time perspective (FTP) is a psychological trait that determines individuals' tendency to think about future events (Koposko \& Hershey, 2014) and the degree to which they consider future states when making decisions about their lives (Van Dalen et al., 2010). It has been shown that individuals with increased future orientation have high levels of conscientiousness, which is related to being organized and efficient (Hershey \& Mowen, 2000) and have fewer tendencies to procrastinate, i.e. they prefer acting now rather than delaying activities for future (Gupta et al., 2012).

The relationship between time orientation and saving for retirement is well established (Jacobs-Lawson and Hershey, 2005; Hershey et al., 2008; Earl et al. 2015). It is demonstrated that those who have a future orientation are more prone to save for the retirement years (Van Dalen et al., 2010). FTP is found to be related positively with self-accounted financial readiness for retirement (Hershey \& Mowen, 2000), and a higher amount of retirement saving contributions (Jacobs-Lawson \& Hershey, 2005).

Thus, we propose the following; 
Proposition 2a. Future oriented individuals are more likely to participate in private pension plans than present oriented individuals.

Proposition 2b. Future oriented individuals are more likely to make larger contributions to their private pension plans than present oriented individuals.

\subsection{Financial Risk Tolerance}

Financial risk tolerance is the extent of ambiguity an individual is comfortable with while making a decision regarding the finances (Grable, 2000). The level of financial risk tolerance is determined by various factors such as gender, age, ethnicity, marital status, occupation, education, wealth and income (Hallahan et al., 2004; van Heinjsbergen, 2010).

Financial risk tolerance is found to be influential in strategies for retirement investment (Grable \& Joo, 1997). For instance, it is seen that individuals with high levels of financial risk tolerance prefer stocks rather than bonds and certificates of deposit in their retirement funds (Hariharan et al., 2000). Van Rooij et al. (2007) investigated risk attitudes towards general matters, financial matters and pension matters and found that for the decisions regarding the pension, individuals acted in the most risk-averse manner choosing the most conservative portfolios of funds. Deaves et al. (2007) reported that individuals who had greater inclination to plan are more risk tolerant and make larger pension contributions.

Based on the above we propose the following:

Proposition 3a. Risk averse individuals are more likely to participate in private pension plans than risk takers.

Proposition 3b. Risk averse individuals are more likely to make larger contributions to their private pension plans than risk takers.

Proposition 3c. Risk averse individuals are more likely to prefer private pension plans with conservative asset allocations than risk takers.

\section{Motivational Factors}

\subsection{Involvement}

Involvement is basically defined as individual's perceived pertinence of an item based on their innate needs, values, and interests (Zaichkowsky, 1985). As a central construct in decision-making, it influences the extent of the search for and evaluation of information. It is generally suggested that a positive relation exists between consumers' level of involvement and their likelihood of purchasing a product (Mittal, 1989). 
Within the retirement and financial preparedness domain, the role of involvement in decisions has been studied extensively. These studies mostly report that as the level of involvement increases so does financial preparedness for retirement (Morgan \& Eckert, 2004; Segel-Karpas \& Werner, 2014). Contrary to that, another study demonstrated that affective involvement to retirement planning is not related to the extent of financial preparation of individuals, whereas cognitive involvement is negatively correlated (Hershey \& Mowen, 2000). The authors interpreted this finding as an indication of concern by these individuals who are not prepared financially for their future and hence becoming more interested in retirement planning. Furthermore, it is noted that as individuals engage in more financial planning activities such as information seeking from various sources, their perceived pension savings adequacy improves (Van Dalen et al., 2010).

The studies examining the impact of varying degrees of involvement on the likelihood planning for retirement and participating to a pension plan are few in number. For instance one study found no significant difference between level of involvement of individuals who bought and who did not buy a pension product (Pallister et al., 2007). However, it is generally indicated that individuals that are vastly involved with a product are frequent buyers (Laurent \& Kapferer, 1985). In accordance with this, Wills \& Ross (2002) found that involvement in retirement decisions has a positive impact on the likelihood of savings for retirement.

Consequently, we propose the following:

Proposition 4a. Individuals, who are involved in retirement planning, are more likely to make larger contributions to their private pension plans than less involved individuals.

Proposition 4b. Individuals, who are involved in retirement planning, are more likely to participate in private pension plans than less involved individuals.

\subsection{Goal Characteristics}

Goals, which are defined as "intentions to realize a desired state" (Antonides and Van Raaij, 1998, p.175) govern behaviors, information search and decision-making processes towards achieving these goals (Austin and Vancouver 1996). Goals are essential in planning for retirement as they aid individuals to contemplate their future and prepare both mentally and financially (Stawski et al., 2007). Moreover, it is suggested that goals help individuals to set a scale to assess saving performance (Koposko \& Hershey, 2014).

Research on saving and retirement planning focused on several distinct goal characteristics. The numbers of goals individuals have is one factor that influences their saving behavior. When individuals possess multiple goals, conflicts arise in the allocation of 
mental resources (Loibl, 2009). It is suggested that having only one goal results in higher saving intentions than having numerous goals since individuals with one goal are more action oriented whereas those with numerous goals tend to compare the goals for significance and urgency and are therefore are more deliberation oriented (Soman \& Zhao, 2011). Another prominent characteristic that has been investigated is goal clarity, which is related to having a clear vision of retirement and setting distinct objectives about quality of life in retirement (Stawski et al., 2007). It is stated that retirement goal clarity influences retirement savings indirectly through planning activities (Hershey et al., 2007; Stawski et al., 2007).

Another characteristic, goal specificity, measures the degree of certainty in the level of desired accomplishment (Wright \& Kacmar, 1994). Within retirement planning context, goal specificity refers to either determining a specific amount for retirement or saving the utmost amount without a particular target. Even though prior studies have not investigated the impact of goal specificity for retirement planning domain, it is stated that level of goal commitment increases with goal specificity (Wright \& Kacmar, 1994). Consequently, it is expected that as goals for retirement become more specific, individuals' commitment to these goals increase, hence the level of their contribution to their retirement plans. Finally, it is indicated that the level of priority of goals increase the level of savings for retirement (Glass \& Kilpatrick, 1998).

Based on the above, we propose the following:

Proposition 5a. Individuals, who have goals that are few in number and more clear, are more likely to participate in private pension plans than those, who have goals that are high in number and less clear.

Proposition 5b. Individuals, who have specific goals for retirement and attach more priority to them, are more likely to make larger contributions to their private pension plans than those who have less specific goals for retirement and attach less priority to them.

\section{Financial Literacy}

Financial literacy -or financial knowledge- can be defined as understanding key financial terms and concepts needed to function daily in a society (Bowen, 2002). Some other definitions of financial literacy in the literature include "the ability to read, analyze, manage and communicate about the personal financial conditions that affect material well-being” (Vitt et al., 2000, p.2), "a basic knowledge that people need in order to survive in a modern society” (Kim, 2001, p.1), “a person's ability to understand and make use of financial concepts” (Servon \& Kaestner, 2008, p.273). There is no standardized instrument to measure 
the construct of financial literacy, mainly due to lack of agreement on its conceptualization and definition (Huston, 2010). Both performance tests and self-report methods have been used in previous literature. This discrepancy led to two dimensions of financial literacy: objective and subjective.

\subsection{Objective Financial Literacy}

Objective financial literacy is measured by performance tests, which are knowledge based and attempt to measure the extent to which individuals are aware of basic finance concepts. Findings suggest that there is a strong correlation between objective and subjective financial literacy (Goldsmith \& Goldsmith, 1997) and that both objective and subjective financial knowledge influence financial behavior in general (Roob \& Woodyard, 2011). Within the context of retirement decisions, Lusardi \& Mitchell (2007) analyzed retired households, indicating that greater objective finance knowledge was associated with planning and succeeding in retirement planning, as well as investing in complex assets such as stocks. The authors also indicated that more knowledgeable consumers thought more about retirement. In accordance with this, individuals with higher objective financial literacy levels have been found to be more likely to save (Grable \& Lytton, 1997) and more likely to participate in private pension system (Agnew et al., 2009; Fornero \& Menticone, 2011; Zanghieri, 2013).

\subsection{Subjective Financial Literacy}

Subjective financial literacy or perceived knowledge can be defined as confidence in knowledge, i.e., how much respondents think they know. It is assessed with self-reports. Courchane (2005) indicated that self-assessed financial knowledge was one of the most significant factors in determining saving decisions. The finding that higher levels of subjective finance knowledge were associated with better retirement preparedness was also confirmed by Hershey et al. (2007).

Based on the above, we propose the following:

Proposition 6a. Both objective and subjective financial literacy have a positive effect on private pension plan participation decision.

Proposition 6b. Both objective and subjective financial literacy have a positive effect on private pension plan contribution levels. 
Proposition 6c. Both objective and subjective financial literacy have a positive effect on the likelihood of preferring complex assets for the private pension plan.

\section{Dispositional and Situational Factors}

\subsection{Mental Construal}

Construal level influences the way an individual mentally represents objects/events; hence has an impact on perception, evaluation and decision processes (Trope \& Liberman, 2010). High level construal is associated with an abstract mindset, which focuses on primary (core) features, positive aspects and desirability concerns of objects/events, low level construal is associated with a concrete mindset, which focuses on secondary (peripheral) features, negative aspects and feasibility concerns (Dhar \& Kim, 2007; Eyal et al., 2004; Freitas et al., 2004; Kray, 2000; Liviatan et al., 2008; Todorov et al., 2007).

Construal level can be studied as both an individual difference variable and a contextual variable. Firstly, individuals have a disposition to construe objects/events in a more abstract (high level) or more concrete (low level) manner. Additionally, situational influences might activate abstract or concrete mindsets with individuals as well. For instance, as temporal distance to objects/events increases, they will be construed at a higher level in an abstract way and as temporal distance to objects/events decreases, they will be construed at a lower level in a concrete way (Liberman \& Trope, 1998; Khan et al., 2011). Van Schie et al. (2013) demonstrated that construal level influences planned retirement age based on both chronic and situational construal levels.

Construal level theory is used to explain the reasons of procrastination in retirement planning. For instance, it is revealed that as individuals get older, their temporal distance to retirement decreases and they have an increased tendency to postpone retirement due to increased number of feasibility concerns. However, for younger individuals retirement is in distant future and attention is on desirability aspects of retirement, so they plan for retirement ages that they cannot afford (Van Schie et al., 2013). Overall, it is suggested that retirement is perceived as a distant future activity hence construed in an abstract way with a focus on the desirability. Yet, the contributions one needs to make to the pension plans are present, near future activities therefore construed in a concrete way with a focus on the feasibility. Consequently, it is seen that people are not willing to undertake concrete costs to realize abstract gains and delay the planning for retirement (Van Heïnsbergen, 2010). To break the cycle of postponement Thaler and Benartzi (2004) developed the SMarT (Save More Tomorrow) program which enabled participants to assign beforehand some percentage of 
their prospective salary raises to their retirement plans. The success of SMarT program is mainly explained by the fact that, as participants are required to start contributing in the future, their temporal distance increase and construe retirement planning in an abstract manner, which emphasizes the positive aspects of the plans (Lynch \& Zauberman, 2006).

We summarize the above discussion in the following two propositions:

Proposition 7a. Individuals, who situationally construe retirement at a higher level (abstractly), are more likely to participate in private pensions than those who situationally construe retirement at a lower level (concretely).

Proposition 7b. Individuals, who dispositionally have high level construal, are more likely to participate in private pensions than those who have low level construal.

\subsection{Regulatory Focus}

Regulatory Focus Theory (RFT) examines the impact of motivational orientation on goal attainment. According to RFT, two types of motivational regulation can be distinguished; namely promotion and prevention focus (Forster et al., 1998). Promotion focus implicates a focus on achieving aspirational and idealistic goals whereas prevention focus implicates a focus on achieving goals related to duties and responsibilities (Shah and Higgins, 1997). Individuals' motivational regulation change based on their predisposition and situational factors. Situational factors can induce a promotion or prevention focus momentarily, and when they align with chronic tendencies both motivation and performance improve (Shah et al., 1998). In relation to RFT, regulatory fit concept has been developed to describe the fit between individuals' goal orientation and the means for attaining that goal. It is suggested that regulatory fit enhances the value ascribed to the final outcome (Avnet \& Higgins, 2006; Higgins, 2000).

Within the financial domain, various studies examined the impact of regulatory focus and regulatory fit on financial decisions and behavior. For instance, it is suggested that regulatory orientation influences individuals' preferences for various investment instruments such that promotion focused individuals were more attentive to gains and preferred stocks and trading accounts, while prevention focused individuals were more attentive to losses and preferred mutual fund or Individual Retirement Account (IRA) investments (Zhou and Pham, 2004). Additionally, it is determined that the attitudes of individuals with a promotion focus are more favorable towards saving for retirement than those of individuals with a prevention focus. Further, it was found that the likelihood of saving for retirement is higher for those who experience a regulatory fit their regulatory focus and saving goals. For a promotion orientated 
individual a promotion saving goal like "saving to enjoy life" increased the likelihood of saving for retirement. Similarly, for a prevention oriented individual, a prevention saving goal like "saving for rainy days" improved the likelihood of saving for retirement (Cho et al., 2014).

Thus we propose the following:

Proposition 8a. Individuals, who situationally experience a regulatory fit, are more likely to participate in private pensions than those who do not.

Proposition 8b. Individuals, who are dispositionally promotion focused, are more likely to participate in private pensions than those who are dispositionally prevention focused.

Proposition 8c. Individuals, who are dispositionally promotion focused, prefer riskier assets for the private pension plans than those who are dispositionally prevention focused.

\section{External Factors}

\subsection{Family Influences}

Current literature identifies family as the primary agent for financial socialization (Sohn et al., 2012). Parents are important role models in money management behaviors, determining financial goals and saving. Therefore, the individuals' willingness to adopt parental financial role modeling should be positively related to their financial attitudes and behaviors. For instance, young people who discuss financial issues with their parents use credit more frequently (Allen et al., 2007). Rickwood and White (2009) note that familial influence has the biggest impact on the extent to which participants prepare for retirement. Advice from family members, especially parents, was found to be the most respected personal source of retirement savings information. Even in cases where participants considered their parents unprepared for retirement, parents were still influential because the individual did not want to experience the same poor retirement lifestyle. For individuals with successful siblings, the siblings were also a significant influence on retirement decisions. Prior research also showed that discussing financial issues with parents had a positive influence on likelihood of saving for retirement among young people (Hancock et al., 2013; Jorgensen and Savla, 2010; Mandell, 2009; Sabri et al. 2010).

Based on the above we propose the following:

Proposition 9. Individuals, who are more influenced by their family, are more likely to participate in private pension plans than those who are less influenced. 


\subsection{Peer Influences}

Studies in the literature have shown that peers are also an important financial socialization agent. An individual may mimic peers because their behaviour might reflect relevant private information or in a desire to conform to social norms (Beshears et al., 2013). It might also be the case that individuals derive utility from their consumption relative to their peers (Abel, 1990). There is a growing empirical literature on how social interactions can affect financial decisions. Studies have shown that parents have a greater influence on individuals at a younger age while peers become more influential as the individual gets older (Brown et al., 1993; Clarke, et al., 2005; Harris, 1995; John, 1999). Duflo and Saez (2003) demonstrated that peers are an important influence in 401(k) plan participation decisions. The authors further found that individuals who were exposed to colleagues who were motivated to enroll in a retirement plan were themselves more likely to enroll. In a more recent study, Beshears et al. (2015) investigated how receiving information about coworkers' behavior affects retirement savings choices and found that peer information increased savings of nonunionized recipients.

Thus we propose the following:

Proposition 10a. Individuals, who are more influenced by their peers, are more likely to participate in private pension plans than those who are less influenced.

Proposition 10b. Individuals, who are more influenced by their peers, are more likely to make larger contributions to their private pension plans than those who are less influenced.

\subsection{Economic Conditions}

Based on economic theory, when stock market crashes or the economy enters into a recession, we would expect to see declines in participation because workers may be reluctant to commit to saving. For workers who continue to participate we would expect to see a decline in contributions because workers may be pessimistic, feel uncertain about their future wages or job prospects, or because their spouses may have lost their jobs in the recession (Butrica \& Smith, 2016). This has also been demonstrated empirically in several studies. For example, Muller and Turner (2011) used the Panel Study of Income Dynamics and found that 401(k) participation is influenced by the performance of the stock market and that fewer individuals participated in private retirement plans during crisis periods. Utkus and Young (2009) investigated the impact of the 2008 crisis on retirement plans and found that a significant portion of participants shifted their asset allocation from stocks to fixed income 
instruments. A study by Smith et al. (2004) found that key life events, such as the birth of a child and the purchase of a home, influence contributions in defined contribution plans. In a more recent study, Butrica and Smith (2016) controlled for earnings, job changes, and other household factors, and found that workers reduce their 401(k) participation and contributions during recessions, suggesting that they may be responding to changes in their expectations about the economy and stock market. The role of economic conditions in shaping retirement saving decisions is even more important for financial consumers in emerging markets with a history of economic instability and crises because participants might lack necessary confidence in the private pension system (Cole et al., 2011).

Therefore, we propose the following:

Proposition 11a. Individuals, who experience favorable economic conditions, are more likely to participate in private pension plans than those who experience poor economic conditions.

Proposition 11b. Individuals, who experience favorable economic conditions, are more likely to make larger contributions to their private pension plans than those who experience poor economic conditions.

Proposition 11c. Individuals, who experience favorable economic conditions, are more likely to prefer stocks in their private pension plans than those who experience poor economic conditions.

\subsection{Institution Based Conditions}

One of the most important influences on retirement plan participation decisions seems to be trust in institutions. Generally, it has been shown that a distrust of financial institutions influences financial behavior (Agnew et al., 2009). Usually, individuals who distrust financial institutions including pension funds avoid doing business with them (Bertrand et al., 2006; Szykman et al., 2005). Similarly, Van Dalen et al. (2010) reported that higher levels of trust in government, pension funds, banks and insurance companies were associated with higher perceived savings adequacy for retirement. Studies have also shown that there is a positive correlation between participation level and employer matching rate (Andrews, 1992; Bassett et al., 1998; Papke, 1995, Papke \& Poterba, 1995). However, the relationship is not linear: increasing matching rate from low to medium levels has a large effect but increasing the rate from medium to high has a small or insignificant effect on participation rates (Kusko et al,, 1998). The existence of employer match has been found to have a positive effect not only on 
participation rate but also on total contribution levels (Benartzi, 2001). The retirement plan's flexibility features such as the option to borrow or the ability to retire early have also a positive effect on participation and contribution rates (Holden \& Vanderhei, 2005)

Based on the above, we propose the following:

Proposition 12a. Trust in institutions, the amount of matching provided by these institutions and the flexibility offered have a positive effect on private pension plan participation decision.

Proposition 12b. Trust in institutions, the amount of matching provided by these institutions and the flexibility offered have a positive effect on private pension plan contribution levels.

\section{Conclusion}

This paper reviewed the factors affecting consumers' private pension plan decisions. The factors discussed included situational and dispositional factors, personality, motivation, financial literacy, and external influences. Based on this survey of literature, we developed a number of propositions, which address the relationship between these factors and private pension plan decisions including participation, contribution rate, and asset allocation. Both individual retirement planners and pension institutions might improve their insight on private pension plan decisions based on this proposed framework.

Evidence suggests that in many countries individuals lack adequate savings for their retirement period (Koposko \& Hershey, 2014). An inclusive understanding of the factors influencing private pension plan decisions will allow managers to be better equipped to propose adequate plan features and develop more fitting strategies to attract consumers. This will benefit not only consumers in increasing their personal welfare and being more financially prepared for their post-employment years but also the economic system by increasing saving rates and reducing the burden on governments. 


\section{References}

Abel, A. (1990). Asset Prices under Habit Formation and Catching up with the Joneses. American Economic Review, Volume 80, Pages 38-42.

Agnew, J., Szykman, L., Utkus, S., \& Young, J. (2009). Literacy, Trust and 401(k) Savings Behavior. Center for Retirement Research Working Paper 2007-10, Boston College.

Allen, M. W., Edwards, R., Hayhoe, C.R., \& Leach, L. (2007) Imagined interactions, family money management patterns and coalitions, and attitudes toward money and credit. Journal of Family and Economic Issues, Volume 28, Pages 3-22.

Andrews, E. S. (1992) The Growth and Distribution of 401(k) Plans. Trends in Pensions, In Eds: Turner, J., Beller, D. Washington, D.C.: U.S. Department of Labor.

Antonides, G., \& Van Raaij, W. F. (1998). Consumer behaviour: A European perspective, Chichester: Wiley.

Austin, J. T., \& Vancouver, J. B. (1996). Goal constructs in psychology: Structure, process, and content. Psychological Bulletin, Volume 120, Pages 338-375.

Avnet, T., \& Higgins T. E. (2006). How regulatory fit affects value in consumer choices and opinions. Journal of Marketing Research, Volume 43, Number 1, Pages 1-10.

Bassett, W. F., Fleming, M. J., \& Rodrigues, A. P. 1998. How Workers Use 401(k) Plans: The Participation, Contribution, and Withdrawal Decisions. Federal Reserve Bank of New York Staff Report, 38 (March).

Bertrand, M. Mullainathan, S., \& Shafir, E. (2006) Behavioral Economics and Marketing in Aid of Decision Making Among the Poor. Journal of Public Policy and Marketing. Volume 25, Number 1, Pages 8-23.

Beshears, J., Choi, J. J., Laibson, D. \& Madrian, B C., (2013). Simplification and saving, Journal of Economic Behavior and Organization, Volume 95(C), Pages 130-145.

Beshears, J., Choi, J. J., Laibson, D., Madrian, B. C. \& Milkman, K. L. (2015), The Effect of Providing Peer Information on Retirement Savings Decisions. The Journal of Finance, Volume 70, Pages 1161-1201.

Bowen, C. F. (2002). Financial knowledge of teens and their parents. Financial Counseling and Planning, Volume 13, Number 2, Pages 93-102.

Brown, B. B., Mounts, N., Lamborn, S. D., \& Steinberg, L. (1993). Parenting practices and peer group affiliation in adolescence. Child Development, Volume 64, Pages 467-482.

Butrica, B. A., \& Smith, K. E. (2016). 401 (k) participant behavior in a volatile economy. Journal of Pension Economics and Finance, Volume 15, Number 1, Pages 1-29.

Cho, S. H., Loibl, C. \& Geistfeld, L. (2014). Motivation for emergency and retirement saving: an examination of Regulatory Focus Theory. International Journal of Consumer Studies, Volume 38, Number 6, Pages 701-711.

Clarke, M. D., Heaton, M. B., Israelsen, C. L., \& Eggett, D. L. (2005). The acquisition of family financial roles and responsibilities. Family and Consumer Sciences Research Journal, Volume 33, Pages 321-340.

Cole, S., Sampson, T., \& Zia, B. (2011). Prices or Knowledge? What Drives Demand for Financial Services in Emerging Markets? The Journal of Finance, Volume 66, Pages 19331967. 
Courchane, M. (2005). Consumer literacy and creditworthiness, Proceedings, Federal Reserve Bank of Chicago.

Deaves, R., Veit, E. T., Bhandari, G., \& Cheney, J. (2007). The savings and investment decisions of planners: A cross-sectional study of college employees. Financial Services Review, Volume 16, Number 2, Pages 117-133

Dhar, R., Kim, E. Y. (2007). Seeing the forest or the trees: Implications of construal level theory for consumer choice. Journal of Consumer Psychology, Volume 17, Pages 96-100.

Duflo, E. \& Saez, E. (2003). The Role Of Information and Social Interactions In Retirement Plan Decisions: Evidence From A Randomized Experiment. Quarterly Journal of Economics, Volume 118, Number 3, 815-842.

Earl, Joanne K., Bednall, T.C., \& Muratore, A. M. (2015). A Matter of Time: Why Some People Plan for Retirement and Others Do Not. Work, Aging and Retirement, doi:10.1093/workar/wau005.

Eyal, T., Liberman, N., Trope, Y., \& Walther, E. (2004). The pros and cons of temporally near and distant action. Journal of Personality and Social Psychology, Volume 86, Pages 781-795.

Fornero, E., \& Monticone, C. (2011). Financial literacy and pension plan participation in Italy. Journal of Pension Economics and Finance, Volume 10, Number 4, Pages 547-564.

Förster, J., Higgins, E. T., \& Idson, L. C. (1998). Approach and avoidance strength during goal attainment: regulatory focus and the "goal looms larger" effect". Journal of personality and social psychology, Volume 75, Pages 1115 - 1131.

Freitas, A. L., Gollwitzer, P. M., \& Trope, Y. (2004). The influence of abstract and concrete mindsets on anticipating and guiding others' self-regulatory efforts. Journal of Experimental Social Psychology, Volume 40, Pages 739 -752.

Goldsmith, E., \& Goldsmith, R. E. (1997). Gender differences in perceived andrealknowledge offinancialinvestments. Psychological Reports, Volume 80, Pages 236-238.

Glass Jr, J. C., \& Kilpatrick, B. B. (1998). Gender comparisons of baby boomers and financial preparation for retirement. Educational Gerontology: An International Quarterly, Volume 24, Number 8, Pages 719-745.

Grable, J. E., \& Joo, S. (1997). Determinants of risk preference: implications for family and consumer sciences professionals. Family Economics and Resource Management Biennial, Volume 2, Pages 19-24.

Grable, J. E. (2000). Financial risk tolerance and additional factors that affect risk taking in everyday money matters. Journal of Business and Psychology, Volume 14, Number 4, Pages 625-630.

Grable, J. E., \& Lytton, R. H. (1997). Determinants of retirement savings plan participation: A discriminant analysis. Personal Finances and Worker Productivity, Volume 1, No. 1, Pages 184-189.

Gupta, R., Hershey, D. A., \& Gaur, J. (2012). Time perspective and procrastination in the workplace: An empirical investigations. Current Psychology, Volume 31, Pages 195-211.

Hancock, A. M., Jorgensen, B. L., \& Swanson, M. S. (2013). College students and credit card use: The role of parents, work experience, financial knowledge, and credit card attitudes. Journal of Family and Economic Issues, Volume 34, No. 4, 369-381. 
Hariharan, G., Chapman, K. S., \& Domian, D. L. (2000). Risk tolerance and asset allocation for investors nearing retirement.. Financial Services Review, Volume 9, Pages 159-170.

Harris, J. R. (1995). Where is the child's environment? A group socialization theory of development. Psychological Review, Volume 102, Pages 458-489.

Hershey, D. A., \& Mowen, J. C. (2000). Psychological Determinants of financial preparedness for retirement. The Gerontologist, Volume 40, Number 6, Pages 687-697.

Hershey, D. A., Jacobs-Lawson, J. M., McArdle, J. J., \& Hamagami, F. (2007). Psychological foundations of financial planning for retirement. Journal of Adult Development, Volume 14, Number 1-2, Pages 26-36.

Higgins, E. T. (2005). Value from regulatory fit. Current Directions in Psychological Science, Volume 14, Volume 4, Pages 209-213.

Holden, S., \& VanDerhei, J. (2005). The Influence of Automatic Enrollment, Catch-Up, and IRA Contributions on 401(k) Accumulations at Retirement. EBRI Issue Brief No. 283. Washington, DC: Employee Benefit Research Institute.

Huston, S. J. (2010). Measuring financial literacy. Journal of Consumer Affairs, Volume 44, Pages 296-316.

Jacobs-Lawson, J. M., \& Hershey, D. A. (2005). Influence of future time perspective, financial knowledge, and financial risk tolerance on retirement saving behaviors. Financial Services Review-Greenwich-, Volume 14, Number 4, Pages 331-344.

John, D. R. (1999). Consumer socialization of children: a retrospective look at twenty-five years of research. The Journal of Consumer Research, Volume 26, Pages 183-213.

Jorgensen, B. L., \& Savla, J. (2010). Financial literacy of young adults: The importance of parental socialization. Family Relations, Volume 59, No.4, Pages 465-478.

Khan, U., Zhu, M.,\& Kalra, A. (2011). When trade-offs matter: The effect of choice construal on context effects. Journal of Marketing Research, Volume 48, Number 1, Pages 62-71.

Kim, J. (2001). Financial knowledge and subjective and objective financial well-being. Consumer Interests Annual, Volume 47, Pages 1-3.

Koposko, Janet L., \& Hershey, D. A. (2014). Parental and Early Influences on Expectations of Financial Planning for Retirement. Journal of Personal Finance, Volume 13, Number 2, Pages 17-27.

Kray, L. (2000). Contingent weighting in self-other decision making. Organizational Behavior and Human Decision Processes, 83, 82-106.

Kusko A. L. Poterba J. M., \& Wilcox D. M. (1998). Employee decisions with respect to 401 (k) plans: evidence from individual-level data. In: Mitchell O, Schieber S (eds) Living with defined contribution pensions: remaking responsibility for retirement. University of Pennsylvania Press, Philadelphia, Pages 98-112.

Laurent, G, \& Kapferer, J.N. (1985). Measuring consumer involvement profiles. Journal of Marketing Research, Volume 22, Pages 41-53.

Liberman, N. \& Trope, Y. (1998). The role of feasibility and desirability considerations in near and distant future decisions: A test of temporal construal theory. Journal of Personality and Social Psychology, Volume 75, Pages 5-18. 
Lim, V. K. Teo, T. S., \& Loo, G. L. (2003). Sex, financial hardship and locus of control: an empirical study of attitudes towards money among Singaporean Chinese. Personality and Individual Differences, Volume 34, Number 3, Pages 411-429.

Liviatan, I. Trope, Y., \& Liberman, N. (2008). The effect of similarity on mental construal. Journal of Experimental Social Psychology, Volume 44, Pages 1256 - 1269.

Loibl, C. (2009). Loosening the belt: on the effects of goal-conflict situations on regular savings. International Journal of Consumer Studies, Volume 33, Number 4, Pages 448-455.

Lusardi, A., \& Mitchell, O. (2007). Financial literacy and retirement preparedness: Evidence and implications for financial education. Business Economics, Volume 42, Number 1, Pages 35-44.

Lynch, J. G.,\& Zauberman, G. (2006). When Do You Want It? Time, Decisions, and Public Policy. Journal of Public Policy and Marketing, Volume 25, Number 1, Pages 67-78.

Mandell, L. (2009). Financial education in high school. In: Overcoming the Saving Slump: How to Increase the Effectiveness of Financial Education and Savings Programs (ed. by A. Lusardi), Pages 257-279. The University of Chicago Press, Chicago.

Mittal, B. (1989). Measuring purchase-decision involvement. Psychology and Marketing, Volume 6, Pages 147-162.

Morgan, L. A., \& Eckert, J. K. (2004). Retirement financial preparation: Implications for policy. Journal of aging and social policy, Volume 16, Number 2, Pages 19-34.

Muller, L., \& Turner, J. (2011). The Persistence of Employee 401(k) Contributions Over a Major Stock Market Cycle: Evidence on the Limited Power of Inertia on Savings Behavior. Upjohn Institute Working Paper, No. 11-174. Kalamazoo, MI: Upjohn Institute.

Pallister, J. G., Wang, H. C., \& Foxall, G. R. (2007). An application of the style/involvement model to financial services. Technovation, Volume 27, Number 1, Pages 78-88.

Papke, L. E. (1995). Participation in and contributions to 401(k) pension plans. Journal of Human Resources, Volume 30, Number 2, Pages 311-325.

Papke, L. E., \& Poterba, J. M. (1995). Survey evidence on employer match rates and employee saving behavior in 401(k) plans. Economics Letters, Volume 49, Pages 313-317.

Perry, V. G., \& Morris, M. D. (2005). Who is in control? The role of self-perception, knowledge, and income in explaining consumer financial Behavior. Journal of Consumer Affairs, Volume 39, Number 2, Pages 299-313.

Plunkett, H. R., \& Buehner, M. J. (2007). The relation of general and specific locus of control to intertemporal monetary choice. Personality and Individual Differences, Volume 42, Number7, Pages 1233-1242.

Rickwood, C. \& White,L. (2009). Pre-purchase decision-making for a complex service: retirement planning. Journal of Services Marketing, Volume 23, Number 3, Pages145-153.

Robb, C. A. \& Woodyard, A. (2011). Financial Knowledge and Best Practice Behavior. Journal of Financial Counseling and Planning, Volume 22, Number 1, Pages 60-70.

Rotter, J. 1966. Generalized expectancies for internal versus external control of reinforcement. Psychological Monographs, Volume 80, Number 1, Whole No. 609, Pages 128. 
Sabri, M.F., MacDonald, M., Hira, T.K., \& Masud, J. (2010). Childhood consumer experience and the financial literacy of college students in Malaysia. Family and Consumer Sciences Research Journal, Volume 38, Number 4, Pages 455-467.

Sakalaki, M., Richardson, C., \& Bastounis, M. (2005). Association of Economic Internality With Saving Behavior and Motives, Financial Confidence, and Attitudes Toward State Intervention. Journal of Applied Social Psychology, Volume 35, Number 2, Pages 430-443.

Segel-Karpas, D., \& Werner, P. (2014). Perceived Financial Retirement Preparedness and Its Correlates A National Study in Israel. The International Journal of Aging and Human Development, Volume 79, Number 4, Pages 279-301.

Servon, L. J., \& Kaestner, R. (2008). Consumer financial literacy and the impact of online banking on the financial behavior of lower-income bank customers. Journal of Consumer Affairs, Volume 42 (Summer), Pages 271-305.

Shah, J., \& Higgins, E. T. (1997). Expectancy× value effects: Regulatory focus as determinant of magnitude and direction. Journal of personality and social psychology, Volume 73, Number 3, Pages 447 - 458.

Shah, J., Higgins, E. T.,\& Friedman, R. S. (1998). Performance incentives and means: how regulatory focus influences goal attainment. Journal of personality and social psychology, Volume 74, Number 2, Pages 285 - 293.

Smith, K. E, Johnson, R. W. \& Muller, L. (2004). Deferring Income in Employer-Sponsored Retirement Plans: The Dynamics of Participant Contributions. National Tax Journal. Volume 57, Number 3, Pages 639-670.

Sohn S. H., Joo, S. E., Grable, J. E., Lee, S., \& Kim, M. (2012). Adolescents' financial literacy: The role of financial socialization agents, financial experiences, and money attitudes in shaping financial literacy among South Korean youth. Journal of Adolescence, Volume 35, Pages 969-980.

Soman, D., \& Zhao, M. (2011). The fewer the better: Number of goals and savings Behavior. Journal of Marketing Research, Volume 48, Number 6, Pages 944-957.

Stawski, R. S., Hershey, D. A., \& Jacobs-Lawson, J. M. (2007). Goal clarity and financial planning activities as determinants of retirement savings contributions. The International Journal of Aging and Human Development, Volume 64, Number1, Pages 13-32.

Szykman, L., Rahtz, D. R., Plater, M. \& Goodwin, G. (2005). Living on the Edge: Financial Services for the Lower Socio-Economic Strata. Working Paper. Williamsburg, VA: The College of William and Mary.

Tang, T. L. P. (1995). The development of a short money ethic scale: Attitudes toward money and pay satisfaction revisited. Personality and individual differences, Volume 19, Number 6, Pages 809-816.

Thaler, R. H., \& Benartzi, S. (2004). Save More Tomorrow (TM): Using Behavioral Economics to Increase Employee Sav ing. Journal of Political Economy, Volume 112, Number 1, Pages 164-188.

Todorov, A., Goren, A., \& Trope, Y. (2007). Probability as a psychological distance: Construal and preferences. Journal of Experimental Social Psychology, Volume 43, Pages 473-482.

Trope, Y., \& Liberman, N. (2010). Construal level theory of psychological distance. Psychological Review, Volume 117, Pages 440-463. 
Utkus, S. P., \& Young, J. A. (2009). Inertia and Retirement Savings: Participant Behavior in 2009. Vanguard Center for Retirement Research https://institutional.vanguard.com/iam/pdf/CRRPB.pdf

Van Dalen, H. P., Henkens, K., \& Hershey, D. A. (2010). Perceptions and expectations of pension savings adequacy: A comparative study of Dutch and American workers. Ageing and Society, Volume 30, Number 05, Pages 731-754.

Van Heïnsbergen, M. (2010). Psychological construal of retirement: How to frame retirement saving information on a website.

http:/alexandria.tue.nl/extra2/afstversl/tm/Van\%20Heijnsbergen\%202010.pdf.

Van Rooij, M. C., Kool, C. J., \& Prast, H. M. (2007). Risk-return preferences in the pension domain: are people able to choose?. Journal of public economics, Volume 91, Number 3, Pages 701-722.

Van Schie, R., Dellaert, B., \& Donkers, B. (2013). Promoting Later Planned Retirement. http://develop.fafo.no/files/news/12470/file133336.pdf.

Vitt, L. A., Anderson C., Kent J., Lyter D.M., Siegenthaler J. K., \& Ward, J. (2000). Personal finance and the rush to competence: Financial literacy education in the U.S.. Institute for Socio-Financial Studies Working Paper, http:/www.isfs.org/documentspdfs/repfinliteracy.pdf 2000.

Wills, L., \& Ross, D. (2002). Exploring the retirement savings gap: An Australian perspective. Pensions Institute, Birckbeck College, http:/hdl.handle.net/10068/443964.

Wright, P. M., \& Kacmar, K. M. (1994). Goal Specificity as a Determinant of Goal Commitment and Goal Change. Organizational Behavior and Human Decision Processes, Volume 59, Pages 242-60.

Zaichkowsky, J. L. (1985). Measuring the involvement construct. Journal of consumer research, 341-352.

Zanghieri, P. (2013). Participation to Pension Funds in Italy: The Role of Expectations and Financial Literacy. Social Science Research Network (SSRN), doi: 10.2139/ssrn.2259758.

Zhou, R., \& Pham, M.T. (2004). Promotion and prevention across mental accounts: when financial products dictate consumers' investment goals. Journal of Consumer Research, Volume 31, Pages 125-135. 